\title{
Contributory Factors of Job Satisfaction and Dissatisfaction in Organizations
}

\author{
Article by Sherena A Persaud \\ Department of Agriculture, University of Guyana \\ E-mail: amela198824@yahoo.com
}

\begin{abstract}
Job satisfaction- dissatisfaction is a major concern to every organization irrespective of the type. As job satisfaction boosts productivity and creates healthy and stress-free employees, job dissatisfaction does the opposite. Job dissatisfaction causes downtime which leads to low productivity and jeopardizes an organization's profitability and long-term security to stay afloat and compete. The aim of this research was to investigate if employees are satisfied in their chosen organization in East Berbice-Corentyne, Guyana. This paper also highlights what is meant by the term "job satisfaction" and "job dissatisfaction" as well as the causes and their effects in organizations. A questionnaire was created and administered to 50 persons from three organizations. Based on the survey carried out, $94 \%$ of the respondents had an appreciation for their job, 36\% stated that they had no issue at their workplace, and 44 out of 50 respondents planned to remain in the organization they are currently apart of despite issues faced.
\end{abstract}

Keywords: job satisfaction, job dissatisfaction, employee withdrawal.

\section{Introduction}

Job satisfaction deals with how much an employee appreciates his or her work environment. Job satisfaction is an evaluation of an individual's current job role (Kalleberg \& Berg, 1987, cited in Mehmood et al., 2012). Employees that are satisfied in his/her organization are willing to work and boost productivity. In addition happy employees are less frustrated and stressed, which leads to a positive attitude in their workplace.

Job dissatisfaction on the other hand deals with how unhappy an employee is in his or her work environment. Job dissatisfaction is a major issue in any organization irrespective of the size of the organization, number of employees, profit, culture, et cetera. Job dissatisfaction matters to everyone in the organization and is very unpleasant (Rosse \& Saturay 2004). This issue can lead to low productivity and conflicts between organizations and their clientele if deadlines are not met or failure to complete projects or orders.

The aim of this paper is to investigate and analyze Job Satisfaction - Dissatisfaction amongst employees and the factors responsible for Job satisfaction - Dissatisfaction.

\section{Literature review}

Employee satisfaction measures how happy an employee is (Ratna \& Singh 2013). If an employee is not content with their work environment, it can be termed as Job dissatisfaction. In any organization, employees are considered to be a vital resource and an important investment, that is, if they are satisfied and loyal to their job (Waqas et al., 2014). Employees that do not feel a sense of appreciation to or from an organization, would not feel the need to go the extra mile for their jobs or want to remain in that environment. This issue may or may not lead to employee withdrawal. Employee withdrawal in an organization can take many behavioral forms, such as, turnover, absenteeism and lateness (Beehr 1978).

Employee withdrawal can be devastating for any organization, as it results in work downtime and resources necessary for hiring new employees and training. In addition, this issue can result in qualified and experienced employees leaving the organization, an asset that may or may not be difficult to be replaced. 
Job satisfaction - dissatisfaction have been investigated by numerous researchers over the past few decades. Two major issues derived from these researches are that organizations simply do not care about employees, only profit. The other issue is that employees always want more and are never satisfied in general. According to researchers Rue and Byers (1992), cited in Indermun \& Bayat (2013), job satisfaction deals with an individual's mental state about their job. Job satisfaction can therefore be of an individual perspective on how they value themselves in their workplace against how the organization treats and values them.

\section{Effects of job satisfaction}

According to Aydin (2009) to create loyal and productivity employees, organizations should try to supply employees expectation in order to achieve satisfaction. Happy and appreciated employees lead to job motivation, which in turns leads to employee productivity and finally employee retention.

\section{Causes of job dissatisfaction}

Issues that employees faced in their everyday work environment that leads to job dissatisfaction are:

Underpaid - employees perceive that they deserve higher salary. Pay can be describes as a reflection of self-worth and is essential for job retention (Noe et al., 2013).

Work overload - this occurs when employees are overburden with tasks that are beyond their capacity to perform or to complete in a short timeframe. Work overload is a major issue in small businesses, where employees are tasked with multiple roles. It can also result from organizations facing constant job turnover, resulting in employees stepping in to get the work done.

Underworked - like work overload, under work can be another major cause of job dissatisfaction. Employees may feel that they can perform or add more value to the organization if given a chance to take on more tasks and challenges.

Conflict with management and conflict with co-workers - employees spend a huge portion of their day in their workplace and interact with management and co-workers on a daily basis. Disputes with management and co-workers can result in employees being unable to effectively interact with their peers, feeling uncomfortable and feeling left out or not part of the group/organization.

Poor working conditions - according to Noe et al. (2013) if an employee feels their health or lives are at risk because of their jobs, then retaining and attracting new potential skills would be difficult. Employees should have safe working conditions and feel that their health and lives matters.

Poor benefits - organizations as a form of appreciation for their employees may offer health plan, dental plan, insurance, leave with pay, incentives, retirement packages, et cetera. These factors give the employees a self-worth that the organization's heads value their contribution.

Stagnant job - this cause of job dissatisfaction occurs with employees that have been in the organization for a long period of time and are tasked with performing the same duties every day. Employees will feel a sense of boredom performing the same routine which will result in a lack of interest and motivation.

Lack of resources - if employees are not given the necessary tools to get their work done in a timely fashion they will eventually get frustrated and be demotivated.

Qualifications do not match the job type - individual may be overqualified for certain jobs which makes them feel demotivated and unappreciated.

Goals do not align with organization - when the goals of the organization are not aligned with the goals of the employee the individual will become uninterested in achieving the goals of the organization.

\section{Effects of job dissatisfaction/ employee withdrawal}

Turnover/retention - Shamsuzzoha \& Shumon (nd) stated that "every organization wished to have high productivity, fewer turnovers and to be profitable. Managing turnover successfully is a must to achieve the above goals". Turnover occurs when an employee is not satisfied with his/her job and physically leaves the organization. This situation can result in work downtime, time and resources necessary for hiring and training of new staff members. 
Lateness - unsatisfied employees not showing an interest towards their duties and responsibilities would tend not to value time and importance of completing their task. This can result in failure to meet deadline and complete important projects which can result in company losses clientele.

Absentee - when an employee is not happy in their working environment they would be reluctant to show up for duty. Absenteeism can cause failure to meet and complete project. This effect of job dissatisfaction can jeopardize the relationship between the organization and their clients.

\section{Methodology}

Data for this project was collected from the following sources:

1) Secondary data: data was collected from literature reviews and books.

2) Primary data: a questionnaire was created to conduct this research. The questionnaire contained pre-coded questions and the likert scale.

For the purpose of this research, purposive sampling was done. The first 50 persons who were currently working on a full time basis willingly took part in this survey.

\section{Limitation}

This research was carried out amongst a tertiary educational institute, spare parts entity and office staff within a rice milling entity located on East Berbice-Corentyne, Guyana and does not reflect any other areas in Guyana.

\section{Result and discussion}

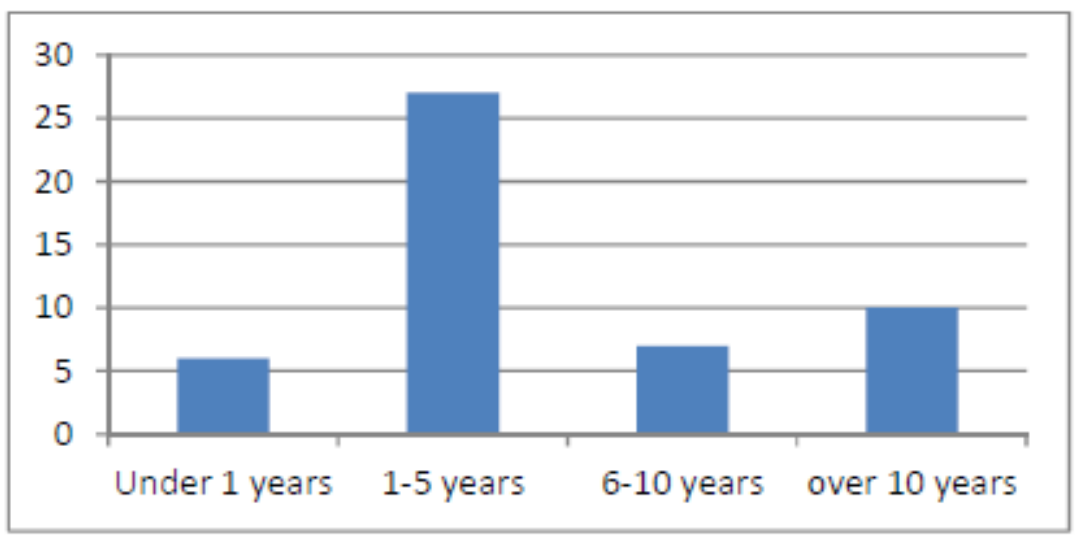

Figure 1. Years of service

Figure 1, shows that out of the 50 respondents, 6 of them have been in their current organization for under a year, while 27 have been there between 1-5 years. Seven respondents were between $6-10$ years and the remaining 10 respondents have been employed in their current organization for over 10 years.

Table 1. Employee earning (GY\$)

\begin{tabular}{|l|l|l|}
\hline Earning (GY\$) & Number of employee & Percentage $(\%)$ \\
\hline Under 50,000 & 0 & 0 \\
\hline $50,000-100,000$ & 42 & 84 \\
\hline $101,000-200,000$ & 6 & 12 \\
\hline Over 200,000 & 2 & 4 \\
\hline
\end{tabular}

From Table 1 above, it can be inferred that $84 \%$ of the respondents earned between GY\$50,000 100,000 , while $12 \%$ were GY\$ $101,000-200,000$ and the remaining $4 \%$ had a earning of over GY\$200,000. 
DOI: $10.21522 /$ TIJMG.2015.04.01.Art001

ISSN: $2520-310 \mathrm{X}$

Table 2. Showing respondents' perceptions regarding different aspect of their jobs

\begin{tabular}{|l|l|l|l|l|l|}
\hline & \multicolumn{3}{|l|}{ Responses (\%) } & Disagree & $\begin{array}{l}\text { Strongly } \\
\text { Disagree }\end{array}$ \\
\cline { 2 - 7 } & $\begin{array}{l}\text { Strongly } \\
\text { Agree }\end{array}$ & Agree & Neutral & & \\
\hline Job appreciation & 50 & 44 & 6 & 0 & 0 \\
\hline $\begin{array}{l}\text { Duties and responsibilities } \\
\text { clearly outlined and } \\
\text { communicated }\end{array}$ & 32 & 54 & 8 & 4 & 2 \\
\hline $\begin{array}{l}\text { Organization goals and } \\
\text { objectives clearly outlined and } \\
\text { communicated }\end{array}$ & 24 & 52 & 22 & 2 & 0 \\
\hline $\begin{array}{l}\text { Organization view employee as } \\
\text { an asset }\end{array}$ & 18 & 48 & 24 & 10 & 0 \\
\hline $\begin{array}{l}\text { Management and colleagues } \\
\text { seems to care }\end{array}$ & 20 & 46 & 22 & 12 & 0 \\
\hline $\begin{array}{l}\text { Management is flexible and } \\
\text { understands the importance of } \\
\text { balancing work and personal } \\
\text { life }\end{array}$ & 24 & 50 & 20 & 2 & 4 \\
\hline
\end{tabular}

In Table 2, a combined sum of $94 \%$ of the respondent stated that they appreciated their job, while $86 \%$ mentioned that their duties and responsibilities were clearly outlined and communicated to them. When asked if the organization goals and objectives were clearly outlined and communicated, 24\% strongly agreed and 52\% agreed, however $22 \%$ stated they were not sure about what were their organizations' goals and objectives. $66 \%$ of the employees felt that the organization considered them to be important to their company, while $10 \%$ felt that they were not important or relevant in their organization. Also in response to if management and colleagues cared about them, $20 \%$ strongly agreed and $46 \%$ agreed that they felt they were appreciated, $12 \%$ did not agree with the statement and felt that they were unappreciated and irrelevant, while $22 \%$ could not decide either way. A total of $74 \%$ of the respondent then went on to say management was flexible and understand the importance of balancing work and personal life, while $20 \%$ were neutral and $6 \%$ disagreed with the statement. With respect to all of the questions proposed during the survey, the majority of respondents had a positive attitude towards their organization.

Table 3. Issues affecting employees in their workplace

\begin{tabular}{|l|l|l|}
\hline Issues affecting employees & $\begin{array}{l}\text { Number of } \\
\text { employees }\end{array}$ & Percentage (\%) \\
\hline Work overload & 3 & 6 \\
\hline Conflict with coworkers & 8 & 16 \\
\hline Conflict with management & 8 & 16 \\
\hline Poor benefits & 15 & 30 \\
\hline Poor working conditions & 11 & 22 \\
\hline Under work & 3 & 6 \\
\hline Stagnant job & 6 & 12 \\
\hline Lack of resources & 11 & 22 \\
\hline Goals not align with organization & 4 & 8 \\
\hline Underpaid & 7 & 14 \\
\hline Qualification do not match job type & 4 & 8 \\
\hline None & 18 & 36 \\
\hline
\end{tabular}


With reference to table 3 , it can be seen that $36 \%$ of the respondents had no issues at work and were satisfied at their workplace. On the other hand the remaining $64 \%$ of the respondents stated that they had some form of issues within their organization. Three major issues employees were facing were poor benefits (30\%), lack of resources (22\%) and poor working conditions (22\%).

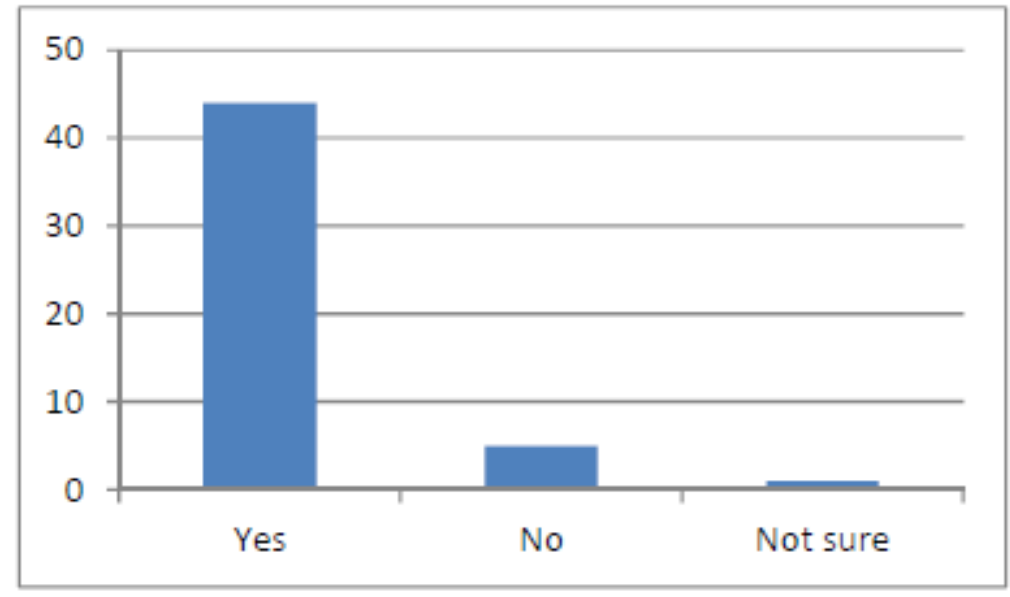

Figure 2. Plans to remain in the organization

From figure 2, it can be inferred that 44 out of the 50 respondents stated that they are planning to remain in their organization, while 5 stated No and 1 was not sure about what to do as yet.

\section{Conclusion}

Job satisfaction is important in any organization. Organizations that experience high rate of job satisfaction and low labour turnover were observed to have less work downtime and high productivity. On the other hand, organizations that face high rate of job dissatisfaction have high labour turnover, absentees and lateness which can lead to work downtime and low productivity.

Based on the research done, employees that took part in the survey showed high rate of job satisfaction as against job dissatisfaction. Even though the majority of the respondents faced some form of issues in their organization, the majority were still satisfied and willing to remain in the organization.

\section{Recommendations}

Based on the survey carried out, the following suggestions were derived;

- Organizations need to review their benefit policy especially for loyal and hardworking employees

- Preservation of all human life is vital for any organization, as such, organizations should adhere to Health and Safety Regulations and no employee should be allowed to work or operate in poor working conditions.

- Lack of resources often result in lack of work or poor work. If organizations want their employees to perform to their fullest potential, then they need to equip them with the necessary resources to perform well.

- Team building exercises and counseling sessions need to be implemented to help coworkers understand and deal with each other.

\section{References}

[1]. Aydin, B \& Ceylan, A 2009, 'A Research Analysis on Employee Satisfaction in terms of Organizational Culture and Spiritual Leadership', International Journal of Business and Management, Vol. 4, No. 3.

[2]. Beehr, T A \& Gupta, N 1978, 'A Note on the Structure of Employee Withdrawal', Organizational Behavior and Human Performance.

[3]. Indermun, V \& Bayat, M S 2013, 'the Job Satisfaction-Employee Performance Relationship: A Theoretical Perspective', International Journal of Innovative Research in Management, Vol. 11, No.2.

[4]. Noe, R A, Lenbeck, J R HC, Gerhart, B \& Wright, P M 2013, 'Human Resource Management: Gaining A Competitive Advantage', 8 Edn. 
DOI: $10.21522 /$ TIJMG.2015.04.01.Art001

ISSN: $2520-310 \mathrm{X}$

[5]. Mehmood, N, Irum, S, Ahmed, K \& Sultana, A 2012, 'A Study Of Factors Affecting Job Satisfaction (Evidence From Pakistan)', Interdisciplinary Journal of Contemporary Research In Business, Vol.4, No. 6.

[6]. Ratna, R \& Singh, P P 2013, 'SHRM Practices and Employee Satisfaction: Study and Relationship', Amity Management Review, Vol. 3, No. 1.

[7]. Rossi, J G \& Saturay, S L 2004, 'Individual Differences in Adaptation to work Dissatisfaction'.

[8]. Shamsuzzoha, AHM \& Shumon, R H nd, 'Employee Turnover-a Study of its Causes and Effects to Different Industries in Bangladesh'.

[9]. Waqas, A, Bashir, U, Sattar, M F, Abdullah, H M, Hussain, I, Anjum, W, Ali, M A \& Arshad, R 2014, 'Factors Influencing Job Satisfaction and Its Impact on Job Loyalty', International Journal of Learning \& Development, Vol. 4, No. 2. 